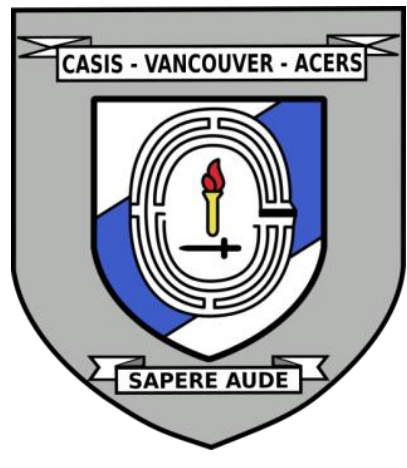

\title{
THE IMPORTANCE OF WARNING INTELLIGENCE WHEN DEALING WITH DRAGONS AND SNAKES
}

Date: November 23, 2021

Disclaimer: This briefing note contains the encapsulation of views presented by the speaker and does not exclusively represent the views of the Canadian Association for Security and Intelligence Studies.

\section{KEY EVENTS}

On November 23, 2021, Dr. David Kilcullen, President and CEO of Cordillera Applications Group, presented The Importance of Warning Intelligence When Dealing with Dragons and Snakes at the 2021 CASIS West Coast Security Conference. The presentation was followed by a question and answer period with questions from the audience and CASIS Vancouver executives. The key points discussed in this presentation included strategic warning times, gray zone attacks, Russian and Chinese strategic deterrence, and the consequences of misunderstanding or underestimating adversaries.

\section{NATURE OF DISCUSSION}

\section{Presentation}

Dr. Kilcullen's presentation focused on the complexity and instability of the security threat environment. Dr. Kilcullen suggested that traditional and linear understandings of strategic warning are outdated and do not accurately reflect the intent of Dragons (state actors) and Snakes (non-state actors). Therefore, we need to adopt a continued and dynamic threat analysis to really analyze, understand, and react to an adversary's changing intent and capability. 


\section{BACKGROUND}

\section{Presentation}

Dr. Kilcullen began by noting the complexity of strategic warning and how it is defined in international affairs. Strategic warning, as he presented it, is indicated by the preparation and mobilization of capabilities of a given country. There are twin conceptual elements of capabilities and intent, and it is the change in capability and intent that creates the strategic warning. Traditionally, capabilitybased planning has been the norm, sometimes projecting into the future, trying to address the distribution of forces to identify strategic shortcomings. However, according to Dr. Kilcullen, this may not be the best way to think about security. The threats posed by an actor could include a spectrum of ongoing gray zone attacks in a dynamic and cross domain context which can intensify or de-intensify at will. For example, Australia was previously thought to be 10 years ahead on strategic warning time for major conventional attacks, but this is rapidly changing, and that length of time is shrinking. Therefore, Dr. Kilkulen posed the question of whether or not we can really analyze, understand, and react to an adversary's changing intent and capability.

To lay the ground for his presentation, Dr. Kilcullen asked to imagine state advisories that we may fight using conventional or asymmetrical means as Dragons and failing states and nonstate actors as Snakes. He then looked at case studies of Russia, China, and non-state actors such as the Taliban and Daesh.

In his case study of Russia, Dr. Kilcullen stated that Russia seeks to be a regional power that can leverage their power over a complex (and in their eyes, threatening) world order. Dr. Kilcullen argued that Russia wants to find its place in a new post-Western world order, without becoming a pawn. Therefore, Dr. Kilcullen noted, Russia practices the art of limited maneuver-doing just enough to achieve their objectives, while maintaining enough plausible deniability to prevent a kinetic conflict. The pre-conflict, or shaping phase of the conflict, has thus become more decisive in face of these new Russian tactics. However, satellite imagery suggests a massive troop buildup on the Ukrainian Russian border. Dr. Kilcullen highlighted that the intent of this fact is reflected through the continued gray zone involvement in places like Belarus; further, what Russia calls "strategic deterrence" is, in fact, a peacetime constant cycle of conflict. Therefore, Dr. Kilcullen stated, the linear assumptions that have formed the basis of strategic warning must be reassessed given the gray conflict. 
As more countries obtain advanced and cheap weapons systems, and as high technology weapons, like loitering munitions, proliferate to less economically developed states, theoretical strategic warning times are drastically reduced. Dr. Kilcullen pointed out that this has been seen through China's response and hostility towards Australia. The People's Republic of China (PRC) is undergoing an unprecedented phase of conventional and asymmetrical military development. Dr. Kilcullen argued that the speed, scope, and aggressiveness of this development is matched in terms of their rhetoric and actions towards Taiwan. Arguably, that is what shifted the Australian view away from a ten-year assumed buildup. Another way to conceptualize this, according to Dr. Kilcullen, is that a hot war is on the way, and we are within that ten-year window right now. Simultaneously, he said, the PRC leadership is making an effort to use a "civilian military fusion doctrine" which includes elements like coercion, theft, and economic warfare. Dr. Kilcullen stated that China's conception of warfare is much broader than our conception of regular warfare. Dr. Kilcullen noted that this is dangerous because China could be acting in a way that they see as warlike, which we misinterpret and thus fail to set off alarm bells to the intelligence community. The opposite could also be true which creates room for misunderstanding.

Finally, misunderstanding adversaries is also important in the context of nonstate actors. Often, non-state actors are underestimated, with the Taliban being the prime example. According to Dr. Kilcullen, the broadest alliance, and certainly the best funded, suffered a humiliating battlefield defeat to a rural and illiterate fighting force drawn from one of the poorest countries in the world. This is what can happen when the intelligence community fails to take the threat of non-state actors seriously. The same was seen with Daesh after they stopped holding territory as the ongoing threat of the organization was diminished. As emphasized by Dr. Kilcullen, we cannot make the mistake of thinking that killing the leaders of non-state actors will cripple the movement. We cannot assume that non-state actors are perfectly rational actors. Therefore, we need a continued and dynamic threat analysis, not the application of traditional and linear understandings of strategic warning.

\section{KEY POINTS OF DISCUSSION}

\section{Presentation}

- When dealing with Snakes and Dragons, we need a continued and dynamic threat analysis, separate from the application of traditional and linear understandings of strategic warning.

The Journal of Intelligence, Conflict, and Warfare Volume 4, Issue 3 
- Threats posed by state actors can include a spectrum of ongoing gray zone attacks in a dynamic and cross domain context which can intensify or deintensify at will.

- The linear assumptions that have formed the basis of strategic warning must be reassessed given the nature of gray conflict.

- As more countries obtain advanced and cheap weapons systems, and as high technology weapons, like loitering munitions, proliferate to less economically developed states, theoretical strategic warning times are drastically reduced.

- Misunderstanding non-state actors can result in the intelligence community failing to take the threats of these adversaries seriously.

(c) $(\ominus \ominus$

EY NC ND This work is licensed under a Creative Commons Attribution-NonCommercial-NoDerivatives 4.0 International License.

(C) (DAVID KILCULLEN, 2022)

Published by the Journal of Intelligence, Conflict, and Warfare and Simon Fraser University

Available from: https://jicw.org/

The Journal of Intelligence, Conflict, and Warfare

Volume 4, Issue 3 